\title{
Difficult Mask Ventilation in Obese Patients: New Predictive Tests?
}

\author{
Obez Hastalarda Zor Maske Ventilasyonu: Yeni Prediktif Testler? \\ ๑ Bengü Gülhan Aydın, • Gamze Küçükosman, • Özcan Pişkin, ๑ Rahşan Dilek Okyay, \\ (1) Hilal Ayoğlu
}

Bülent Ecevit University Faculty of Medicine, Department of Anesthesiology and Reanimation, Zonguldak, Turkey

Abstract

\begin{abstract}
Aim: The aim of our study was to evaluate specific factors in predicting difficult mask ventilation (DMV) in obese patients undergoing elective surgery.
\end{abstract}

Methods: This prospective and observational study was performed in 90 obese patients. We assessed age, height, weight, sex, body mass index (BMI), dental structure, presence of facial hair, modified Mallampati test result, mouth opening, thyromental distance (TMD), sternomental distance, mandibular protrusion, mandibular length, neck circumference (NC), neck length, upper lip bite test result, height to TMD ratio, NC to TMD ratio (NC/TMD), and history of snoring and Obstructive Sleep Apnea syndrome for estimation of DMV.

Results: The mean age of the patients was $40.9 \pm 9.4$ years and the mean BMl was $44.7 \pm 6.2 \mathrm{~kg} / \mathrm{m}^{2}$. Of all patients $38.9 \%$ were determined to have DMV. Clinical variables associated with DMV were male gender, mandibular length, snoring, NC, and NC/TMD. Multiple logistic regression analysis showed that male gender $(p=0.047)$ and snoring ( $p=0.02$ ) were independent factors.

Conclusion: We believe that NC/TMD and ML are predictive tests for DMV in obese patients. Tests and measurements at the bedside are not sufficient alone and we believe that they will be more reliable when considered together

Keywords: Mandibular length, mask ventilation, neck circumference/ thyromental distance, obesity.
Öz

Amaç: Çalışmamızın amacı elektif cerrahi uygulanan obez hastalarda maske ventilasyonunun zorluğunun belirlenmesinde spesifik faktörlerin etkisini değerlendirmektir.

Yöntemler: Bu prospektif ve gözlemsel planlanan çalışmaya 90 hasta dahil edildi. Zor maske ventilasyonu (ZMV) tahmininde yaş, boy, kilo, cinsiyet, vücut kitle indeksi (VKi), diş yapısı, sakal varlığı, modifiye mallampati testi, ağız açıklığı, tiromental mesafe (TM), sternomental mesafe, mandibula protrüzyonu, mandibula uzunluğu (MU), boyun çevresi (BÇ), boyun uzunluğu, üst dudak ısırma testi, boyun çevresi/ tiromental mesafe (BÇ/TM) oranı, horlama ve obstrüktif sleep apne sendromu varlığının etkisini değerlendirdik.

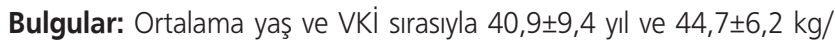
$\mathrm{m}^{2}$ idi. Olguların \%38,9'unun ZMV olduğu belirlendi. ZMV ile ilişkili klinik değişkenler erkek yaş, MU, horlama, $\mathrm{BÇ}$ ve $\mathrm{BÇ/TM}$ oranı idi. Çoklu regresyon analizi, erkek cinsiyetin $(p=0,047)$ ve horlamanın $(p=0,02)$ bağımsız faktörler olduğunu ortaya koymuştur.

Sonuç: Obez hastalarda BÇ/TM ve MU'nun ZMV için prediktif testler olduğunu düşünüyoruz. Yatak başı yapılan testler ve ölçümlerin tek başına yeterli olmadığını, birlikte değerlendirildiğinde daha güvenilir olacağına inanıyoruz

Anahtar Sözcükler: Mandibular uzunluk, maske ventilasyonu, boyun çevresi/tiromental mesafe, obezite.

\section{Introduction}

Obesity is generally acknowledged as a global phenomenon that increases morbidity and reduces life expectancy (1). According to World Health Organization data, in 2014, there were more than 1.9 billion overweight adults worldwide, above the age of 18 , and more than 600 million obese people. Thus, most patients requiring anesthesia for surgery will be overweight or obese $(2,3)$.
Address for Correspondence/Yazışma Adresi: Bengü Gülhan Aydın

Bülent Ecevit University Faculty of Medicine, Department of Anesthesiology and Reanimation, Zonguldak, Turkey

Phone: +90 5305583076 E-mail: bengukoksal@gmail.com ORCID ID: orcid.org/0000-0002-1324-6144

Received/Geliş Tarihi: 24 January 2018 Accepted/Kabul Tarihi: 18 June 2018
${ }^{-}$Copyright 2019 by The Medical Bulletin of University of Health Sciences Haseki Training and Research Hospital

The Medical Bulletin of Haseki published by Galenos Yayınevi.

Telif Hakkı 2019 Sağlık Bilimleri Üniversitesi Haseki Eğitim ve Araştırma Hastanesi Haseki Tip Bülteni, Galenos Yayınevi tarafından yayınlanmıştır. 
The Fourth National Audit Project on major complications of airway management in the United Kingdom reported that obese patients had double the risk of airway problems and morbidly obese patients were four times more likely to develop airway problems during an anaesthetic (4). In obese patients, not only the external airway but also the anatomy of the oropharynx and larynx is altered. Without regard to the total body fat of obese patients, parapharyngeal fat dimensions increase in parallel with visceral and abdominal fat distribution.

Obesity is related to restrictive pulmonary disease due to increased intraabdominal pressure. This reduces functional residual capacity, causing low oxygen reserves, disrupted gas exchange and shortened safe apnea time before desaturation. As a result, it is known that there is a limited duration to solve airway problems in "can't intubate, can't ventilate" situations (5-7).

In obese patients, difficult airway management, especially difficult mask ventilation (DMV), is frequently reported (8). The incidence of DMV in obese individuals has been reported to be $1.4-24 \%$ (8-10). According to the American Society of Anesthesiologists (ASA), DMV is defined as the clinical situation developing when it not possible for the anesthesiologist to provide adequate ventilation because of one or more of the following problems: inadequate mask seal, excessive gas lead or excessive resistance to the ingress or egress of gas (11).

In our study, the aim was to determine predictive factors for DMV or impossible mask ventilation (IMV) in obese patients with low physiological reserve to ensure preparation of appropriate airway choices.

\section{Methods}

Our study was performed between May and November 2014 after obtaining approval from the Bülent Ecevit University Ethics Committee (meeting no: 201484-08/04) and patient consent. This prospective and observational study included 90 obese ASA 1-3 patients aged 18-65 years with a body mass index (BMI) $\geq 30$ who underwent elective surgery under general anesthesia. Patients requiring regional anesthesia, awake and/or rapid intubation or emergency entubation, and pregnant patients were excluded.

The patients were preoperatively assessed for age, height, weight, BMI, dental structure, presence of beard, modified Mallampati test results, mouth opening [interincisor gap $(\mathrm{cm})]$, thyromental distance $(\mathrm{cm})$, sternomental distance $(\mathrm{cm})$, mandibular protrusion, mandibular length $(\mathrm{ML})$, neck circumference (NC), neck length, upper lip bite test, height to thyromental distance ratio (RHTMD), NC to TMD (NC/TMD), history of snoring, and Obstructive Sleep Apnea syndrome (OSAS) by an anesthesiologist blind to the study.

\begin{tabular}{|l|l|}
\hline \multicolumn{2}{|l|}{ Table 1. Mask ventilation scale(12) } \\
\hline Grade & Grade description \\
\hline 1 & Ventilated by mask \\
\hline 2 & $\begin{array}{l}\text { Ventilated by mask with oral airway/other adjuvant } \\
\text { with or without muscle relaxant }\end{array}$ \\
\hline 3 & $\begin{array}{l}\text { Difficult mask ventilation (inadequate to maintain } \\
\text { oxygenation, unstable or requiring two practitioners } \\
\text { with or without muscle relaxant) }\end{array}$ \\
\hline 4 & $\begin{array}{l}\text { Unable to mask ventilate with or without muscle } \\
\text { relaxant }\end{array}$ \\
\hline
\end{tabular}

All patients had no premedication with routine monitoring. All patients received preoxygenation with $100 \% \mathrm{O}_{2}$ for 5 minutes using appropriate masks. Anesthesia was induced with $2 \mathrm{mg} / \mathrm{kg}$ propofol and $1 \mu \mathrm{gg} / \mathrm{kg}$ fentanyl according to total body weight, and rocuronium $0.6 \mathrm{mg} /$ $\mathrm{kg}$ according to ideal body weight. The patients had mask ventilation with the head positioned $30^{\circ} \mathrm{C}$ up. Mask ventilation and intubation were performed by the same anesthesiologist blind to the study. Mask ventilation was graded according to a four point scale described by Han et al. (12) (Table 1). All patients were intubated without problems with a video laryngoscope (Storz C-MAC ${ }^{\circledR}$ Video Laryngoscope, Germany).

\section{Statistical Analysis}

Statistical Package for the Social Sciences (SPSS) v.19.0 (IBM Corp. in Armonk, NY) was used for statistical analysis. Descriptive statistics are given with frequency and percentage for categorical variables and mean, standard deviation, median and minimum-maximum values for continuous variables. The Shapiro-Wilk test was used to evaluate the normality of the variables. The independent samples t-test and the Mann-Whitney $U$ test were used for normally distributed and non-normally distributed variables, respectively. Yates' correction and Fisher's exact tests were used to test relationship between categorical variables. All variables with a $p$ value below 0.05 in univariate analysis were entered into a multivariate logistic regression model. For all statistical comparisons, a p value of less than 0.05 was considered statistically significant.

\section{Results}

A total of 90 patients (58 female and 32 male) with a mean age of $40.9 \pm 9.4$ years and a BMI of $44.7 \pm 6.2 \mathrm{~kg} / \mathrm{m}^{2}$ were included in the study. Of all the patients $38.9 \%$ were determined to have DMV. Surgeries were, in order, bariatric surgery $(76.7 \%)$, lumbar disc hernia $(6.7 \%)$, shoulder surgery (3.3\%), percutaneous nephrolithotomy (3.3\%), abdominal surgery (2.2\%), and thyroidectomy (7.8\%). The other patient characteristics are shown in (Table 2). In univariate analysis, risk factors for DMV were identified. There was a significant difference in the presence of history of snoring and OSAS, NC $\geq 43 \mathrm{~cm}$, male gender, 


\begin{tabular}{|c|c|}
\hline Age (year) $\pm S D$ & $41 \pm 9$ \\
\hline $\mathrm{F} / \mathrm{M}(\%)$ & $58 / 32(64.4 / 35.6 \%)$ \\
\hline Height $(\mathrm{cm}) \pm$ SD & $163 \pm 9$ \\
\hline Weight $(\mathrm{kg}) \pm$ SD & $118 \pm 19$ \\
\hline BMI $\left(\mathrm{kg} / \mathrm{m}^{2}\right) \pm \mathrm{SD}$ & $43.6 \pm 6.2$ \\
\hline Mallampati: $1 / 2 / 3(\%)$ & $10 / 58 / 22(11.1 / 64.4 / 24.4 \%)$ \\
\hline ASA: $1 / 2 / 3(\%)$ & $4 / 66 / 20(4.4 / 73.3 / 22.2 \%)$ \\
\hline Beard (\%) & $17(18.9 \%)$ \\
\hline History of snoring (\%) & $74(82.2 \%)$ \\
\hline OSAS diagnosis (\%) & $8(8.9 \%)$ \\
\hline $\begin{array}{l}\text { Sternomental distance } \geq 12.5 \mathrm{~cm} \\
(\%)\end{array}$ & $81(90 \%)$ \\
\hline $\mathrm{TMD} \geq 6 \mathrm{~cm}(\%)$ & $88(97.8 \%)$ \\
\hline $\mathrm{ML} \geq 9 \mathrm{~cm}(\%)$ & $86(95.6 \%)$ \\
\hline Mask numbers: $3 / 4 / 5(\%)$ & $5 / 46 / 39$ (5.6/51.1/43.3\%) \\
\hline $\begin{array}{l}\text { Upper lip bite test grade: } 1 / 2 / 3 \\
(\%)\end{array}$ & $59 / 31 / 0(65.6 / 34.4 / 0 \%)$ \\
\hline Neck circumference \pm SD & $44 \pm 4.4$ \\
\hline $\mathrm{NC} / \mathrm{TMD} \pm \mathrm{SD}$ & $4.8 \pm 1.09$ \\
\hline RHTMD \pm SD & $18.4 \pm 3.63$ \\
\hline
\end{tabular}

\begin{tabular}{|c|c|c|c|}
\hline Variables & Easy DMV; \% & Difficult DMV; \% & $p$ \\
\hline F/M & $\begin{array}{l}46.7 \% \\
14.4 \%\end{array}$ & $\begin{array}{l}17.8 \% \\
21.1 \%\end{array}$ & $p=0.006$ \\
\hline $\begin{array}{l}\text { History of snoring } \\
\text { No } \\
\text { Yes }\end{array}$ & $\begin{array}{l}15(27.3 \%) \\
40(72.7 \%)\end{array}$ & $\begin{array}{l}1(2.9 \%) \\
34(97.1 \%)\end{array}$ & $p=0.008$ \\
\hline $\begin{array}{l}\text { History of OSAS } \\
\text { No } \\
\text { Yes }\end{array}$ & $\begin{array}{l}53(65.4 \%) \\
2(22.2 \%)\end{array}$ & $\begin{array}{l}28(34.6 \%) \\
7(77.8 \%)\end{array}$ & $p=0.025$ \\
\hline $\begin{array}{l}\text { NC } \\
<43 \mathrm{~cm} \\
\geq 43 \mathrm{~cm}\end{array}$ & $\begin{array}{l}46.7 \% \\
14.4 \%\end{array}$ & $\begin{array}{l}17.8 \% \\
21.1 \%\end{array}$ & $p=0.013$ \\
\hline $\begin{array}{l}\text { NC/TMD } \\
<5 \mathrm{~cm} \\
\geq 5 \mathrm{~cm}\end{array}$ & $\begin{array}{l}43(78.2 \%) \\
12(21.8 \%)\end{array}$ & $\begin{array}{l}19(54.3 \%) \\
16(45.7 \%)\end{array}$ & $p=0.021$ \\
\hline $\begin{array}{l}\text { ML } \\
<9 \mathrm{~cm} \\
\geq 9 \mathrm{~cm}\end{array}$ & $\begin{array}{l}0 \\
55 \text { (61.1\%) }\end{array}$ & $\begin{array}{l}4(4.4 \%) \\
31(34.4 \%)\end{array}$ & $p=0.02$ \\
\hline
\end{tabular}

Table 4. Independent predictors of difficult mask ventilation according to multivariate logistic regression model

\begin{tabular}{|l|l|l|l|l|l|l|l|l|}
\hline & B & SE & Wald & df & $\mathbf{p}$ & Exp (B) & \multicolumn{2}{|l|}{ 95\% Cl of Exp (B) } \\
\cline { 3 - 9 } & & & & & & & Lower & Upper \\
\hline Fixed & 17.096 & 18808.6 & 0.000 & 1 & 0.999 & - & - & - \\
\hline Male sex & -1.317 & 0.516 & 6.520 & 1 & 0.011 & 0.268 & 0.097 & 0.736 \\
\hline Snoring & 2.646 & 1.137 & 5.415 & 1 & 0.020 & 14.097 & 1.518 & 130.906 \\
\hline NC/TMD & 0.398 & 0.246 & 2.625 & 1 & 0.105 & 1.489 & 0.920 & 2.409 \\
\hline NC/TMD: Neck circumference/thyromental distance, Cl: Confidence interval, SE=stantard error & & & \\
\hline
\end{tabular}

$M L \geq 9 \mathrm{~cm}$ and NC/TMD $<5 \mathrm{~cm}$ were significantly different between patients with and without DMV (Table 3).

To estimate easy and DMV, the variables of history of snoring, sex and NC/TMD were taken into the model. Since only four patients had a ML below $9 \mathrm{~cm}$, ML was removed from the model. The remaining three variables explained $35.7 \%$ of the variation in easy/DMV, with snoring and sex observed to be significant ( $p=0.020$ and 0.011 ) for differentiation of easy/DMV. Snoring was assessed to increase the risk of DMV by 14.097 times while being a male increased the risk by 3.73 times (Table 4).

\section{Discussion}

Currently, the prevalence of obesity and accompanying health risks continue to increase. Difficulties in securing mask ventilation and airway in obese patients are common (13). Difficult airway is defined as a situation where a conventionally-trained anesthesiologist encounters difficulty with face mask ventilation, intubation or both (14). The most dangerous situation in airway management is the situation where tracheal intubation is difficult or impossible and ventilation with a mask is insufficient or cannot be completed (patients who can't be intubated or ventilated). The prediction of DMV is therefore of vital importance (11). The incidence of DMV in the general population and obese patient population has been reported to be $1.4-24 \%$ and $8.8-14 \%$, respectively $(9,10,15-18)$. In our study, the incidence of DMV was found to be $38.9 \%$. Contrary to other studies, the male percentage in our study was higher which we believe may 
have caused the difference. The incidence of IMV is much lower than that of DMV. Langeron et al. (9) reported that only one patient in 1502 (0.07\%) had IMV, and Kheterpal et al. (15) reported an incidence of $0.16 \%$. In our study, no patient was observed to have IMV.

In their study, Langeron et al. (9) reported that age $>55$ years, BMI $>26 \mathrm{~kg} / \mathrm{m}^{2}$, edentulous mouth, history of snoring and presence of facial hair were independent factors for DMV. Kheterpal et al. (15) indicated BMI of 30 $\mathrm{kg} / \mathrm{m}^{2}$ or greater as the most important factor for grade 3 DMV. In studies of obese patients, independent factors for DMV were reported to be male gender, large NC, high Mallampati score, limited jaw protrusion, and age $\geq 49$ years $(17,18)$. In our study, univariate analysis revealed that the risk factors were history of snoring, history of OSAS, $N C \geq 43 \mathrm{~cm}$, male gender, $M L \geq 9 \mathrm{~cm}$, and $N C / T M D<5 \mathrm{~cm}$.

Many factors contribute to DMV, facial anomalies are among common reasons. Long and narrow mandible is a common facial anomaly. Cavities formed at the corners of the mouth and lower corners of the mask may cause air leak and DMV $(19,20)$. In a study assessing the effect of horizontal $\mathrm{ML}$ on endotracheal intubation difficulty, a $\mathrm{ML}<9 \mathrm{~cm}$ was determined to be a predictive factor for difficult intubation $(p<0.001)(21)$. In our study, there was a significant effect of $\mathrm{ML}$ above $9 \mathrm{~cm}$ on the incidence of DMV $(p<0.02)$.

$\mathrm{BMI}$ and waist circumference have been reported to contribute to the prediction of non-abdominal, abdominal subcutaneous and visceral fat. They are the first steps to determine the distribution and level of obesity (22). Recently, NC has been used to define excessive weight and obesity. NC is positively correlated with age, weight, waist and hip measurements in both sexes. Additionally, NC is considered an upper body obesity index $(23,24)$. Increased fat tissue in the pharyngeal walls causes changes in the anatomy of the upper airway. Deposition of fat in the lateral walls reduces the airway diameter and the oropharynx gains an elliptical shape. As NC reflects increased palatal and pharyngeal soft tissue, it may make mask ventilation and intubation difficult (25). In a study that compared the ease of intubation in obese and lean patients with intubation difficulty scale, they showed difficult intubation in patients with a NC of more than 35 $\mathrm{cm}$ (26). Cattano et al. (18) reported that a $\mathrm{NC} \geq 40 \mathrm{~cm}$ in the general population and $\geq 43 \mathrm{~cm}$ in obese patients was correlated with DMV ( $p=0.002)$. Another study found that the best discriminating point for $\mathrm{NC}$ was $46 \mathrm{~cm}$, with the risk of DMV increasing linearly as NC increased (17). In our study, a cut-off value for NC was identified as $43 \mathrm{~cm}$, and we believe that in accordance with the literature $N C \geq 43$ $\mathrm{cm}$ is correlated with DMV $(p=0.01)$.

Obesity is believed to predispose individuals to OSAS because of mass loading of the upper airway by adipose tissue in the neck (27). Approximately $5 \%$ of morbidly obese patients have OSAS (28). Horner et al. (29) showed that there was more fat in areas surrounding the collapsible segments of the pharynx in patient with OSAS on magnetic resonance imaging. In another study, it was stated that male sex and high adipose tissue distribution were associated with poorer pulmonary gas exchange (30). Snoring is an indicator of increased upper airway resistance and possible OSAS. Several studies suggested that the prevalence of habitual snoring was strongly dependent on $\mathrm{BMI}$ and $\mathrm{NC}(31,32)$. As a result, obese patients with OSAS or increased risk of OSAS or snoring history have an increased risk of DMV and difficult intubation $(33,34)$. In our study, in accordance with the literature, the incidence of DMV was high in those with OSAS diagnosis and history of snoring $(p=0.03, p=0.008)$.

Studies researching new indices for difficult intubation reported that, evaluation of RHTMD and NC/TMD might be useful screening for difficult intubation $(35,36)$. The literature is silent as no study has been done in adults to find the relationship of DMV with RHTMD and, NC/ TMD. In our study of obese patients, of these parameters, only a NC/TMD $<5 \mathrm{~cm}$ was identified to have a statistically significant effect on DMV $(p<0.021)$.

\section{Conclusion}

In conclusion, male sex, snoring history, $\mathrm{NC} \geq 43 \mathrm{~cm}$, $\mathrm{ML} \geq 9 \mathrm{~cm}$ and $\mathrm{NC} / \mathrm{TMD}<5 \mathrm{~cm}$ were correlated with DMV in obese patients.

The sample size is small to conclusively state the results of our study if we compare with similar studies in adults. Further studies with larger sample size are needed for investigation of new indices, such as ML, NC/TMD, and RHTMD in the obese population.

We assume that NC/TMD and ML measurements are predictive tests for DMV in obese patients. As preoperative airway examination should be carefully completed, especially in obese patients, tests and measurements at the bedside are not sufficient alone and we believe that they will be more reliable when considered together. In case of difficulties in predicting DMV and placement of any airway apparatus, we suggest that airway equipment such as face mask, oral/nasal airway, laryngeal mask should be prepared or different airway methods should be planned.

\section{Authorship Contributions}

Surgical and Medical Practices: B.G.A., Ö.P. Concept: B.G.A., G.K., H.A. Design: H.A., R.D.O. Data Collection or Processing: Ö.P., G.K., R.D.O. Analysis or Interpretation: B.G.A., H.A., Literature Search: G.K., R.D.O., Ö.P. Writing: B.G.A.

Conflict of Interest: No conflict of interest was declared by the authors. 
Financial Disclosure: The authors declared that this study received no financial support.

\section{References}

1. Parameswaran K, Todd DC. Soth M. Altered respiratory physiology in obesity. Can Respir J 2006;13:203-10.

2. World Health Organization Unhealhty Diets and Physical Inactivity Fact Sheet June 2009. http://www.Who.int/nmh/ publications/fact_sheet_diet_en.pdf.

3. Pedoto A. Lung physiology and obesity: Anesthetic Implication for Thoracic Procedures Anesthesiol Res Pract 2012;2012:154208.

4. Cook TM, Woodall N, Frerk C. Fourth National Audit Project. Major complications of airway management in the UK: results of the Fourth National Audit Project of the Royal College of Anaesthetists and the Difficult Airway Society. Part 1: anaesthesia. Br J Anaesth 2011;106:617-31.

5. Arens R, Sin S, Nandalike K, Rieder J, et al. Upper airway structure and body fat composition in obese children with obstructive sleep apnea syndrome. Am J Respir Crit Care Med 2011;183:782-7.

6. Pelosi P, Croci M, Ravagnan I, et al. Total respiratory system, lung, and chest Wall mechanics in sedated-paralyzed postoperative morbidly obese patients. Chest 1996;109:144-51.

7. Juvin $\mathrm{P}$, Lavaut $\mathrm{E}$, Dupont $\mathrm{H}$, et al. Difficult tracheal intubation is more common in obese than in lean patients. Anesth Analg 2003;97:595-600.

8. Langeron $O$, Birenbaum A, Le Saché $F$, et al. Airway management in obese patient. Minerva Anestesiol 2014;80:382-92.

9. Langeron $\mathrm{O}$, Masso E, Huraux C, et al. Prediction of difficult mask ventilation. Anesthesiology 2000;92:1229-36.

10. Yildiz TS, Solak $M$, Toker $K$. The incidence and risk factors of difficult mask ventilation. J Anesth 2005;19:7-11.

11. Binks A, Pyke M. Anaesthesia for the obese patient. Anaesthesia \& Intensive Care Medicine 2008;9:299-302.

12. Han R, Tremper KK, Kheterpal S, et al. Grading scale for mask ventilation. Anesthesiology 2004;101:267.

13. Noble DW, Mccallum F. Anaesthesia for the obese patient. Anaesthesia \& Intensive Care Medicine 2004;5:92-95.

14. Apfelbaum JL, Hagberg CA, Caplan RA, et al; American Society of Anesthesiologists Task Force on Management of the Difficult Airway. Practice guidelines for management of the difficult airway: an updated report by the American Society of Anesthesiologists Task Force on Management of the Difficult Airway. Anesthesiology 2013;118:251-70.

15. Kheterpal S, Han R, Tremper KK, et al. Incidence and predictors of difficult and impossible mask ventilation. Anesthesiology 2006;105:885-91.

16. Williamson JA, Webb RK, Szekely S, et al. Difficult intubation: an analysis of 2000 incident reports. Anaesth Intens Care 1993;21:602-7.

17. Leoni A, Arlati S, Ghisi D, et al. Difficult mask ventilation in obese patients: analysis of predictive factors. Minerva Anestesiol 2014;80:149-57.

18. Cattano D, Katsiampoura A, Corso RM, Killoran PV, Cai C, Hagberg CA. Predictive factors for difficult mask ventilation in the obese surgical population. F1000Res 2014;3:239.
19. El-Orbany M, Woehlck HJ. Difficult mask ventilation. Anesth Analg 2009;109:1870-80.

20. Sanuki T, Watanabe T, Ozaki Y, et al. Upside-down mask ventilation technique for a patient with a long and narrow mandible. Anesth Prog 2014;61:169-70.

21. Khan ZH, Maleki A, Makarem J, et al. A comparison ofthe upper lip bite test with hyomental/thyrosternal distances and mandible length inpredicting difficulty in intubation: A prospective study. Indian J Anaesth 2011;55:43-6.

22. Janssen I, Heymsfield SB, Allison DB, et al. Body mass index and waist circumference independently contribute to the prediction of nonabdominal, abdominal subcutaneous, and visceral fat. Am J Clin Nutr 2002;75:683-8.

23. Ben-Noun LL, Sohar E, Loar A. Neck circumference as a simple screening measure for identifying overweight and obese patients. Obes Res 2001;9:470-7.

24. Ben-Noun LL, Laor A. Relationship between changes in neck circumference and changes in blood pressure. Am J Hypertens 2004; 17:409-14.

25. Mayer P, Pépin JL, Bettega G, et al. Relationship between body mass index, age and upper airway measurements in snorers and sleep apnoea patients. Eur Respir J 1996;9:1801-9.

26. Shailaja S, Nichelle SM, Shetty AK, Hegde BR. Comparing ease of intubation in obese and lean patients using intubation difficulty scale. Anesth Essays Res 2014;8:168-74.

27. Shelton KE, Woodson H, Gay S, et al. Pharyngeal fat in obstructive sleep apnea. Am Rev Respir Dis 1993;148:462-6.

28. Adams JP, Murphy PG. Obesity in anaesthesia and intensive care. Br J Anaesth 2000;85:91-108.

29. Horner RL, Mohiaddin RH, Lowell DG, et al. Sites and sizes of fat deposits around the pharynx in obese patients with obstructive sleep apnoea and weight matched controls. Eur Respir J 1989;2:613-22.

30. Zavorsky GS, Christou NV, Kim DJ, et al. Preoperative gender differences in pulmonary gas exchange in morbidly obese subjects. Obes Surg 2008;18:1587-98.

31. Peker $Y$, Hedner J, Norum J, et al. Increased incidence of cardiovascular disease in middle-aged men with obstructive sleep apnea: a 7-year follow-up. Am J Respir Crit Care Med 2002;166:159-65.

32. Svensson $M$, Lindberg $E$, Naessen $T$, et al. Risk factors associated with snoring in women with special emphasis on body mass index: a population-based study. Chest 2006;129:933-41.

33. Toshniwal G, McKelvey GM, Wang H. STOP-Bang and prediction of difficult airway in obese patients. J Clin Anesth 2014;26:360-7.

34. Hiremath AS, Hillman DR, James $A L$, et al. Relationship between difficult tracheal intubation and and obstructive sleep apnoea. Br J Anaesth 1998;80:606-11.

35. Kim WH, Ahn HJ, Lee CJ, et al. Neck circumference to thyromental distance ratio: a new predictor of difficult intubation in obese patients. Br J Anaesth 2011;106:743-8.

36. Krobbuaban B, Diregpoke S, Kumkeaw S, et al. The predictive value of the height ratio and thyromental distance: four predictive tests for difficult laryngoscopy. Anesth Analg 2005;101:1542-5. 